\title{
KEZDŐKÖR
}

\section{Párválasztást befolyásoló tényezők az egyetemista nők körében}

\author{
KUKUCSKA ZSUZSA ${ }^{1}$
}

\begin{abstract}
ABSZTRAKT
A tanulmány középpontjában a felsőoktatásban tanuló női hallgatók párválasztását befolyásoló tényezői állnak. Kutatási kérdésként jelenik meg, hogy a házasság intézménye továbbra is kiemelkedő helyen szerepel-e a felsőoktatásban résztvevő női hallgatók körében, mint tervezett kapcsolati forma? Illetve a magasabb iskolai végzettséggel rendelkező egyén magasabb iskolai végzettségű személlyel alakít-e ki párkapcsolatot, ezzel kapcsolati homogámiát megvalósítva? A párválasztás alakulása ezáltal a házasság, az élettársi kapcsolat valamint a halasztási mechanizmus vizsgálata mellett kerül bemutatásra, a partnerszelekciót befolyásoló tényezókön túl, melyek elemzésére egy tíz fös kvalitatív kutatás keretében kerül sor. A faktorok között pedig megjelenik az életkor, a lakóhely, a származás és a vallási hovatartozás, illetve a szülőről való leválás, valamint az iskolai végzettség, az anyagi tôke és munkaerôpiaci helyzet, a párkapcsolat tervezett időtartama és az információs kor hatásai.
\end{abstract}

KULCSSZAVAK: párválasztást befolyásoló tényezők, család, házasság, élettársi kapcsolat

\section{ABSTRACT}

\section{Factors that influence matechoice among college women}

The centre of the study is the influential factors of female students in higher education. As a research question, does the institution of marriage continue to be a prominent place among female students in higher education as a planned relationship? And, does a person with a higher education level of education develop a relationship with a higher educated person, therefore achieving homogeneity of relationship? Thereby the choice of coupling is presented in addition to the examination of marriage, cohabitation and postponement mechanism, beyond the factors influencing partner selection, which are analyzed in a qualitative research of tenpersons. Factors include age, place of residence, origin and religion, separation from parenting, educational attainment, material capital and labor market situation, planned duration of the relationship and effects of the information age.

KEYWORDS: influential factors in a mating, family, marriage, cohabitation

\footnotetext{
${ }^{1}$ Szociálpolitika MA szakos hallgató, Debreceni Egyetem, Szociológia és Szociálpolitika Tanszék.
} 


\section{KEZDŐKÖR}

\section{Bevezetés}

Jelen tanulmány a felsőoktatási intézményekben tanuló női hallgatók párválasztását, valamint a választást befolyásoló tényezőket vizsgálja - szakirodalmi illetve interjús kutatásra támaszkodva. A célcsoport indokoltságát a jelenleg fennálló nemi tendenciák adják - a Statisztikai tükör 2015-2016. évi adatai női dominanciáról számolnak be a felsőoktatásban. A partnerek kiválasztásának meghatározó tényezői lehetnek a szocio-demográfiai változók, mint például az életkor, a származás, vagy akár a lakóhely, a vallási nézetek. Mindemellett befolyásoló tényezőként jelenhet meg a gazdasági-anyagi háttér, az iskolai végzettség - melyekre a tanulmány szintén figyelmet fordít. A partnerválasztás szempontjából feltehető a kérdés, hogy a párválasztás során használatos két tétel közül melyik érvényesül. A felek párkapcsolati homogámiára, azaz hasonlóságra törekednek, vagy ennek szöges ellentéte figyelhető-e meg, azaz a párkapcsolati heterogámia, vagyis a különbözőség? Kiemelt aspektusként kerülnek bemutatásra a felsőoktatásban tanuló egyének körében mindazon kapcsolati formák, amelyeket elsődlegesen preferálnak, illetve az, hogy a különböző együttélési formákkal kapcsolatban milyen kialakult nézeteik, véleményeik vannak. Fontos ugyanakkor, hogy a tanulmányban vázolt következtetések nem feltétlenül érvényesek a női hallgatók teljes körére a felsőoktatásban, a kutatás kvalitatív jellege miatt.

A vizsgálat középpontjában azon befolyásoló tényezők állnak, amelyek meghatározhatják a partnerszelekciót. A jellemvonások személyenként más-más sorrendben szerepelhetnek, esetleg fel sem merülnek. Továbbá a tanulmány a különböző magánéleti eseményekhez kapcsolódva - például a szülői ház elhagyásának időpontja, az első párkapcsolat kialakítása, vagy akár az első házasságkötés időpontja - jeleníti meg a 21. századi kitolódott párválasztási életkorokat. Az események bizonyos szinten összekapcsolódnak az egyéni életutakban, s alakítják kapcsolataikat.

Kutatási kérdésként fogalmaztam meg, hogy a házasság intézménye továbbra is kiemelkedő helyen szerepel-e a felsőoktatásban résztvevő női hallgatók körében, mint tervezett kapcsolati forma? Illetve a magasabb iskolai végzettséggel rendelkező egyén magasabb iskolai végzettségú személlyel alakít-e ki párkapcsolatot, ezzel kapcsolati homogámiát megvalósítva?

\section{A partnerszelekciót megalapozó elméletek}

Mai tudásunk szerint a családi értékek változásokon mentek keresztül. Megjelent azok csoportja, akik úgy vélik, hogy az első házasságnak nem feltétlenül kell örök érvényűnek lenni - lehetőség van a változtatásra, a házasságból való kilépésre (Albert - Farkas - Leveleki 2002). A házasságkötések számát tekintve 1960-ban szinte 


\section{KEZDŐKÖR}

minden nő élete folyamán legalább egyszer megházasodott, 1990-ben négyből három állapodott meg, 2000-ben viszont már csupán minden második. 2010-ben pedig a nők 39 százalékára volt jellemző. A jogi aktus megkötésének egyéni életútban bekövetkező ideje esetében is folyamatos növekedés figyelhető meg (Pongrácz 2011, 2012, Murinkó 2013). A nők a rendszerváltás idején 21-22 éves korban kötöttek házasságot, a férfiak pedig 24-25 éves korban. 2010-ben viszont már a nők 29 évesen, a férfiak 31 évesen léptek a házasság intézményébe (Bukodi 2002a, Murinkó 2013). A 2017-es adatok értelmében pedig a fiatalok 44 százaléka azonnal házasságot kötne az általa megfelelőnek vélt partnerrel, míg 45 százalékuk együttélést követően lépne a házasság intézményébe (Engler 2018).

A párkapcsolatok alakulásának szempontjából csökkent a házasságok aránya, $\mathrm{s}$ ezzel párhuzamosan nőtt az élettársi kapcsolatok aránya. Elterjedésének egyik oka lehet, hogy az egyén sokkal könnyebben hagy fel az adott kapcsolatával, amennyiben az megromlik, mint házasság esetén, amely hosszabb időt - és papírmunkát - vesz igénybe (Albert - Farkas - Leveleki 2003). Ugyanakkor fontos megállapítani, hogy vannak, akiknek csupán egyfajta választott kapcsolati forma, míg másoknak kényszerként jelenik meg. Hiszen az anyagi háttér, a munkaerőpiacon elfoglalt hely, vagy az esetleges inaktivitás visszatartó tényező lehet a házasságtól (Tóth 2012). Bukodi Erzsébet (2001, 2002a, 2002b, 2004) vizsgálatai szerint az élettársi kapcsolat azáltal, hogy kevesebb beruházást igényel, jobban illik az iskolai részvétel időszakához. Ez idő alatt az egyén számos bizonytalansággal találkozik, és csupán szerény anyagi forrással rendelkezik. A 2000-es évekre jellemző tendenciaként a magasabb iskolai végzettséggel rendelkező személyek könnyebben kerülték meg a házasságra ösztönző társadalmi nyomásokat, gyakrabban részesítették előnyben az élettársi kapcsolatokat, vagy az alternatív együttélési formákat. Ezzel szemben S. Molnár Edit (2001) szerint európai viszonylatban igaz, hogy a magasan képzettek választják az alternatív együttélési formákat, Magyarországon ez mégsem vált jellemzővé a 2000-es években. Nálunk inkább az alacsonyan képzettek választják az élettársi kapcsolatot - bár az elmúlt évtizedben bizonyos fokú javulás tapasztalható az iskolai végzettség szerinti összetételben. Az alacsonyabb végzettségűek körében való elterjedés magyarázatául szolgálhat a rossz anyagi háttér, valamint a kedvezőtlen jövedelmi szint. A kutatás később e megállapításokra is reflektál a hallgatók jövőbeli elképzeléseinek tekintetében, az interjús kutatás által.

Az alternatív együttélési formák közé sorolhatjuk például a látogató partnerkapcsolatot (LAT - Living Apart Together). Ebben az esetben a felek elköteleződnek egymás iránt, nem alakítanak ki másokkal hosszabb-rövidebb kapcsolatokat, de nem élnek közös háztartásban. Maga az életforma lehet szándékos, de akár külső befolyásoló hatás miatt kialakult kényszeres forma is. Intenzitásukban szintén eltérések figyelhetőek meg - egyesek szinte minden nap találkoznak, míg mások csupán hetente pár alkalommal (Pongráczné 2011). A párkapcsolatban élő felek együttélé- 


\section{KEZDŐKÖR}

se ugyanakkor próbaházasságnak is tekinthető, amennyiben felmerül a házasodási kedv. Mindazonáltal összehasonlító vizsgálatokra alapozva Végh József (2010) - aki kortünetként jelöli meg a házasság nélküli együttélést - megállapította, hogy a próbaházasságban élő felek gyakrabban élnek át konfliktusokat, és esetenként boldogtalanabbak, mint azok, akik házasságban élnek. Maga az életforma már az 1990-es években is megfigyelhető volt, amely egyfajta meggyőződésre is lehetőséget ad a mai napig. A felek az együttélés kapcsán eldönthetik, hogy az adott partnerük alkalmas vagy esetleg alkalmatlan a későbbi házasságra - $\mathrm{s}$ a feltérképezésnek köszönhetően alakíthatják kapcsolatukat (Bukodi 2001, 2002a, 2002b).

A kapcsolati formák esetében a nőtlenek/hajadonok arányára növekvő tendencia jellemző (Murinkó - Rohr 2018). Utasi Ágnes véleménye szerint ezt a növekedést „a fiatalok fokozott individualizálódása, az értékpreferenciák és családformák átalakulása, a magyar férfiak korai halandósága és a párkapcsolati formák pluralizálódása együtt alakítja" (Utasi 2001: 117). Csoportjukra a 2014-es Statisztikai tükör két különálló jelenséget határozott meg. Az egyikbe mindazok az egyedülálló fiatalok tartoznak, akik tudatosan vagy épp akaratlanul választják az egyedüllétet. Körükre a „szingli” életforma megnevezést alkalmazza. A másik elkülönített kollektíva tagjai azok, akik csupán halasztják az önálló életük kezdetét, így ők a megszokott életkoron túl is a szülői háznál maradnak (Statisztikai tükör 2014). Pistyur Veronika (2003) szintén e két típusú megkülönböztetést alkalmazta kutatása során. A jelenségek differenciálására a „kényszerszingli” valamint a „meggyőződéses szingli” elnevezést használta. Az első kategóriába tartozó egyének azok, akiknél az egyedülállóság csupán átmenetileg áll fenn. A második kategória tagjai azonban tudatosan választják az adott életformát. Továbbá rámutat a parazitaszingli kifejezésre is, amely csoportba a munkaviszonnyal rendelkező személyek tartoznak, akik önálló jövedelmük ellenére továbbra is a szülői háznál élnek és szüleikkel is tartatják el magukat.

\section{Partnerszelekciós koncepciók}

Bereczkei Tamás szavait idézve az emberi párválasztás „a szociális viselkedés egyik legbonyolultabb és legösszetettebb jelensége" (Bereczkei 2012: 157). A gyermekkori család mint elsődlegesen befolyásoló faktor minden társadalomban megjelenik. A párválasztáshoz szükséges nézetek is a családban alakulnak ki elsőként. Ez a viselkedésmód ugyanakkor társadalmilag "kódolt”, és öntudatlan is egyben, mivel normák és generációk közötti átadásokon nyugszik. A tudatos oldalát pedig a társadalomtudomány által közvetített elvek jelentik (Buda - Szilágyi 1988). Az átadott viselkedési módok természetesen koronként és társadalmanként változnak.

Az idealizált partner képe, melyet az egyén kezdetben szimpatikusnak talál, majd vonzódik hozzá, erősen összefügg az énképpel és az énideállal, azaz az önértékeléssel. A partnerhez füzött reményeket befolyásolhatják a gyermeki példák is, mint pél- 


\section{KEZDŐKÖR}

dául a szülőkép, a szülőknél látott viselkedési formák (Buda - Szilágyi 1988). A bevésődésnek („imprinting”) is fontos szerepe van, hiszen „a szülőkkel folytatott korai kapcsolatokból származó tapasztalatok formálják az utód későbbi viselkedését, szociális kompetenciáját" (Bereczkei - Rozsnyai - Vekerdy 2012: 37). Ennek egy bizonyos válfaja, amikor az első partnerhez válnak hasonlóvá a választott társak. Az idealizált pár képe továbbá a szépségideállal, a divat befolyásoló hatásával is összefüggésbe hozható, amely koronként és társadalmanként változó (Buda - Szilágyi 1988).

A párválasztás pszichológiai oldalról is megközelíthető, s különböző elméletekkel, tételekkel támasztható alá. Ide sorolható például a lélektani hasonlóság elmélete, amely alapján a kapcsolat akkor a legkiegyensúlyozottabb, ha a párkapcsolatba lépő személyek tulajdonságai, érdeklődési körei a leginkább fedik egymást. Ezzel ellentétben a komplementaritás tétele kimondja, hogy azok a kapcsolatok tekinthetőek erősebbnek, amelyekben a partnerek személyiségében különbségek figyelhetőek meg, melyek egymást kiegészítik (Buda 2002). Ez utóbbi két tézis utal a homogenitásra (azonosságra) és heterogenitásra (különbözőségre) vonatkozó törekvésekre. A Halo-effektus, azaz holdudvarhatás alapján pedig az egyén vonzalmát felülértékelt jegy vagy jegyek adják. A partnerrel kapcsolatos tudatos elképzelések ugyanakkor nem találhatóak meg a párkapcsolat kialakulásakor. Kizárólag annak felbomlását követően fogalmazódnak meg az asszertív, azaz tudatos igények. Azonban az utólagos értékelés már az új helyzetnek megfelelően formálódik. A szülők, a barátok - azaz a külső környezet - jelzése a rossz végkimenetelü kapcsolatra mindaddig háttérbe szorul az egyén számára, amíg a szerelem tart². Azt követően azonban amennyiben a kapcsolat ténylegesen felbomlik - az érintett személyek alátámasztják a korábbi nézeteket, s ezzel mintegy önvédelmi torzítások mennek végbe (Buda - Szilágyi 1988). Kutatásom szempontjából további két fő tézis releváns. Egyrészt a közelségi hipotézis szerint a gyakori találkozások akár a vonzalom kialakulásához is vezethetnek (Lőrincz 2006) ${ }^{3}$. Másrészt a szülőimágó keresésének elmélete alapján nagyobb valószínűséggel fog beleszeretni azon személybe az egyén, aki leginkább megtestesíti az ellentétes nemű szülőben szeretett és tisztelt tulajdonságokat. Ebben az esetben előfordulhat, hogy ha negatív kép él benne az édesanyjáról/édesapjáról, akkor a párkapcsolata során kiemelkedő figyelmet fordít arra, hogy a partnere ne rendelkezzen ugyan azokkal a jellemzőkkel (Buda - Szilágyi 1988).

${ }^{2}$ Ilyen esetben gyakori jelenség, hogy gyengülnek a baráti kapcsolatok, hiszen a partner egyben a barát szerepét is betölti, így nincs szüksége úgymond az egyénnek más baráti felekre. A probléma csupán akkor jelenik meg, ha a kapcsolat véget ér és nem csak a szerelmét, hanem a barátját is elveszíti az adott személy, s nem marad más, akihez ezt követően fordulhatna.

${ }^{3}$ A partnerszelekciós elméletek feltárására Buda Bélán és Szilágyi Vilmoson túl Lőrincz László is hangsúlyt fektetett. A vonzalom szabályai (2006) című tanulmányában több párválasztási modellt, elméletet és hipotézist írt le, mint például a csereelméletet, a befektetési modellt, az evolúció elméletet, a kirostálási hipotézist, az inger - érték - szerep (SVR) elméletet, valamint az összecsiszolódási elméletet. 


\section{KEZDŐKÖR}

\section{A partnerszelekciós tényezők szociológiai megközelítése}

Az életkorbeli különbségeket figyelembe véve az esetek többségében a férfi az idősebb (Buda - Szilágyi 1988, Dienes 2014). Magyarázatként jelenhet meg, hogy „a nők sokkal inkább vonzódnak az idősebb, tapasztaltabb férfiakhoz, mint a férfiak az idősebb, tapasztaltabb nőkhöz" (Szilágyi 1978: 99). Mindez több okra vezethető vissza. Ilyen lehet például a férfi partner státusza, anyagi helyzete, egzisztenciája. Az idősebb férfi számára pedig a nő a fiatal szépséget testesítheti meg. Az életkori különbségek alapján pedig a 20 év körüli nők esetében sokkal magasabb a szerelemre vágyók aránya férfitársaikkal szemben. Mindennek indokaként szolgál, hogy az adott életkorban a nők érettebbek a párválasztásra (Szilágyi 1978).

A származási háttér magába foglalja az egyén értékorientációját, kulturális és gazdasági tőkéjét, valamint azt a közeget, amelyből - ha nem kerül ki - párt választ. Az utóbbi évtizedekben viszont a származáson alapuló befolyásoló tényező hatása fokozatosan gyengül (Bukodi 2004, 2005). Ugyanakkor a felmerülő társadalmi eltérések kiküszöbölése érdekében a fiatalok hasonló társadalmi helyzetű társat választanak partnerszelekciójuk során. A folyamat nem tudatos, viszont a hasonló beállítottságú fiatalok jobban és probléma mentesebben alakítják ki egymás közti kapcsolataikat (Buda - Szilágyi 1988).

A lakóhely mint befolyásoló faktor is megjelenik például az ismerkedési színterek $^{4}$ esetében. Ez természetesen függ a település nagyságától is. Egy kisebb lélekszámú településen szinte „mindenki ismer mindenkit”, amely bizonyos esetekben megnehezítheti a párválasztást. Erőteljesebben megjelenhet a külső környezet befolyásoló ereje, amely esetenként hátráltathatja az egyén döntését - leginkább akkor, ha nem egyeznek az elképzelések. Egy nagyvárosi miliőben már nem feltétlenül áll fenn ez a helyzet, sőt előfordulhat, hogy csupán a megismerkedés kapcsán derül fény az azonos lakóhelyre.

A vallási alapon kialakuló homogám kapcsolatok jelentősége a század elején volt megfigyelhető, hiszen akkor még a párok közel 90 százaléka tartozott ugyanabba a felekezetbe. A vallási tekintetben heterogén házasságok aránya később emelkedik (Bukodi 2002a). S manapság már csak a szorosan kapcsolódó egyházi csoportokban jelenik meg a homogámiára való törekvés.

${ }^{4}$ Ismerkedési színtereket korábban a családi összejövetelek, színházi események, esetleg a vallási közösségek jelentettek. A mai modern korban viszont a helyszínek szempontjából is változások következtek be. A munkahelyre, szórakozóhelyekre, internetes felületekre került nagyobb hangsúly - a régiek pedig valamelyest feledésbe merültek. 


\section{KEZDŐKÖR}

\section{A szülőrőll való leválás mint befolyásoló faktor}

„A párválasztási szocializáció alakulása szempontjából igen jelentős a szülőkhöz való érzelmi kötődések fokozatos lazulása, ill. átalakítása és a jó baráthoz, majd a partnerhez való érzelmi kötődés képességének kialakulása." (Szilágyi 1978: 66) A fiatalok körében mindkét nem esetében nő azon időintervallum, amelyet a szülői háznál töltenek. Ezáltal egyre inkább elterjedt a posztadoleszcencia jelensége, vagyis az utóserdülőkor. A 18. életévét betöltött gyermek tovább tanul, nem dolgozik, s mindezek mellett a szülői háznál lakik, tehát gyermek státuszban marad. Ennek következtében a 2011-es adatok értelmében a 20-24 éves korosztály 71\%-a, míg a 25-29 évesek 43\%-a él továbbra is a szülői háznál (Monostori - Murinkó 2015).

Érdekes jelenség az is, hogy a magasan képzett, magas jövedelmű szülők esetében előfordulhat, hogy a fiatal nem érez késztetést az otthon elhagyására, hiszen a szülők finanszírozzák kiadásaikat, vágyaikat. A magas igényekből és elvárásokból fakadóan emellett el sem szeretnének költözni mindaddig, míg önmaguk képesek nem lesznek kielégíteni szükségleteiket. Ez a kettős helyzet egymás ellentéteként is értelmezhető. Amennyiben a szülő finanszírozza kiadásait, nem érez késztetést a munkavállalásra, viszont anélkül önmaga nem lesz képes a felmerülő igényeinek pénzbeli teljesítésére. A magasan kvalifikált szülők hatása továbbá a gyermek oktatási intézményben eltöltött éveinek számában is megfigyelhető. Az iskolapadban töltött évek során pedig a diákoknak nem feltétlenül nyílik lehetősége a megfelelő partnerkapcsolat kialakítására. Ezzel mintegy ellentétet képezve megfigyelhető, hogy az alacsonyabb végzettségű szülők esetében elfogadottabb a gyermekük korai párválasztása (Bukodi 2004). Ugyanakkor az a jelenség is észlelhető, amikor a szülők nem szeretnének gyermekeik nélkül élni, hiszen nélkülük „kihaltnak” tűnne a családi ház (Murinkó 2013).

A szülők hatása a választott partnerkapcsolati típus jellegében is megnyilvánulhat. Bukodi Erzsébet (2001, 2002b) korábbi, külföldi vizsgálatok eredményeit felhasználva vázolta az összefüggéseket a szülők válása és a gyermek párkapcsolati formájának kiválasztása között. Következtetése szerint gyakrabban választanak nem-házas együttéléseket az egyszülős családban felnövekvő fiatalok. A szülők véleményei pedig a partnerrel kapcsolatban is megjelenhetnek. Előfordulhat, hogy a szülő, gyermeke partnerét nem találja megfelelőnek fia/lánya mellé. Meglehet, hogy úgy gondolja, nem testesíti meg mindazokat, az általa fontosnak vélt tulajdonságokat, amelyekre a gyermekének szüksége van. Tehát a szülők hozzáállása, elképzelése nagymértékben meghatározhatja az egyén párválasztását, amennyiben azt az adott személy „megengedi”. 


\section{KEZDŐKÖR}

\section{A halasztási mechanizmus jelensége}

Folyamatosan növekszik azon személyek száma, akik a 20. születésnapjukig nem létesítettek tartós partnerkapcsolatot (Spéder - Kapitány 2007, Murinkó 2013, Murinkó - Rohr 2018). Ugyanakkor a magyar fiatalok továbbra is családközpontú gondolkodással jellemezhetőek. Az egyetemisták körében szintén tapasztalható a házasodási kedv, a családtervezés. A nemek között pedig nincsenek jelentős különbségek, csupán az időzítésben figyelhető meg némi eltérés, kitolódás (Székely - Szabó 2016).

\section{Az iskolai végzettség mint befolyásoló faktor}

A párválasztás azon formája, melyet az iskolai végzettség vezérel „teljesítménycentrikusnak" nevezhető. Jelenléte az utóbbi évtizedekben is megfigyelhető, hiszen az iskolázottságon alapuló párkapcsolati homogámia előtérbe került. Az azonos kvalifikációjú személyek elsődlegesen egymást preferálják, amelyre három mögöttes tényező szolgálhat magyarázatul. Bizonyos mennyiségű kulturális tőkemegjelenítője, az aktuális munkaerőpiaci lehetőségek előrejelzője, valamint a jövőbeni foglalkozási lehetőségek mutatója is lehet (Bukodi 2002a, 2004, 2005).

Az iskolai végzettség által kialakított hierarchikus szintek csúcsán elhelyezkedő személyek számára az egymás közötti partnerkapcsolat kialakítása fő szempontként jelenhet meg. Ezáltal az alacsonyan képzettek kénytelenek egymással párkapcsolatokat kialakítani, annak ellenére, hogy a felfelé irányuló kapcsolatok megfelelőbbek lennének számukra. Kvalifikációjuk által viszont nem jelentenek ideális partnert a magasan képzett személyeknek. Tehát mindkét nem esetében megállapítható, hogy a minél magasabb végzettségű személy megtalálása érdekként jelenhet meg. $\mathrm{Az}$ egyéneket ezáltal már a kvalifikációjuk is kelendőbbekké teheti (Bukodi 2004).

\section{Az anyagi tôke és a munkaerőpiaci helyzet mint befolyásoló faktor}

A párválasztás során mindkét fél számára befolyásoló faktorként jelenhet meg az anyagi háttér, hiszen ezáltal következtetéseket vonhatnak le az adott személy életvitelével kapcsolatban is. Továbbá a párkapcsolat elmélyülésekor is szempontként szerepelhet (a felmerülő költségek értelmében). Tehát a kétkeresős modell nagyobb egzisztenciális biztonságot nyújthat nők és férfiak számára egyaránt. Mindezek értelmében mindkét fél részéről érdekként jelenik meg a saját erőforrásaikhoz mért legjobb gazdasági esélyekkel bíró partner megtalálása. Ez egyfajta vertikális kizárásként is értelmezhető, hiszen az alacsonyabb státusszal bíró csoportok nem azért homogámok, mert nem szeretnének magasabb pozíciójú személyekkel házasodni, hanem azért, mivel bizonyos fokig ki vannak zárva az ilyen típusú házasságokból. 


\section{KEZDŐKÖR}

Ehhez pedig a munkaerőpiacon elfoglalt kedvezőtlen helyzetük is hozzájárulhat (Kalmijn 1994 idézi Bukodi 2004). Ugyanakkor Szilágyi Vilmos (1978) megállapítása szerint a gazdasági szempontok folyamatosan háttérbe kerülnek a párkapcsolatok és a házasságkötések során. Helyüket pedig az intellektuális, emocionális és szexuális igények kölcsönös kielégítése veszi át. Feltehető a kérdés, hogy az 1970-es évekbeli megállapítás vonatkoztatható-e a jelenlegi helyzetekre is? A kutatás empirikus része többek között az anyagi szempontok vizsgálatán túl a jövőbeli munkaerőpiaci helyzet kérdésének megválaszolását is célul tűzte ki.

\section{A párkapcsolatok tervezett idôtartamának hatása}

A partnerszelekciót erősen befolyásolja a kapcsolat tervezett időtartama. Hiszen a partner kiválasztása során a jellemzővonásokat tekintve, nem feltétlenül azonos ideáltípusok figyelhetőek meg a hosszú és a rövid távú kapcsolatok tervezése során. A férfiak például kategóriákat alakítanak ki magukban. Ezek alapján vannak a „rendes” és a „könnyen kapható lányok”. A szexuális kapcsolataik beteljesítését általában a második kategóriába sorolható személyekre korlátozzák, miközben erősen kötődnek egy „rendes lány” idealizált képéhez (Buda - Szilágyi 1988). Ez esetben is megfigyelhetőek az időbeli lehatároltságokból adódó eltérések.

Hosszú távú partnerkapcsolat kialakításakor a legfontosabb jellemvonások közé tartozik a „megértő, intelligens, érzelmekben gazdag, nyitott” tulajdonságok (Buss 1989 idézi Bereczkei - Rozsnyai - Vekerdy 2012: 42). Ugyanakkor az igények szempontjából a nemek szerint is vannak bizonyos eltérések. A férfiaknál elsődleges a testi vonzerő, a szépség, a megjelenés. E jellemvonások akár a reproduktivitásra is visszavezethetőek, hiszen azt a párt fogja választani, aki mind genetikailag, mind szellemileg a számára legtökéletesebb gyermeket fogja világra hozni. A nők esetében pedig megfigyelhető, hogy kiemelkedő hangsúlyt fektetnek a megbízhatóságra, az őszinteségre és az intelligenciára. De mindezek mellett számításba veszik párjuk foglalkozását és bevételeit, valamint társadalmi helyzetét (Buda - Szilágyi 1988, Bereczkei - Rozsnyai - Vekerdy 2012).

A rövidtávú kapcsolatok kialakítása során pedig bizonyos tényezők, mint a hoszszú távú kapcsolatok kialakítása során, nem feltétlenül jelennek meg. Az intim viszony létesítéséhez viszont bizonyos mértékű bizalomra szükség van, de ez közel sem azonos a hosszútávon megjelenő biztonság igényével, hiszen ekkor a csak fizikai vonzalom válik dominánssá.

\section{Az információs kor hatása}

Manapság a modernizáció hatására információs korban élünk (Tari 2015). Mindennapi életünk számos területén megtalálhatóak a különböző technikai eszközök, me- 


\section{KEZDŐKÖR}

lyek átszövik a kapcsolatainkat, munkánkat és a szabadidőnket is behálózzák. A párkapcsolatok létesítése terén szintén nagy változásokat hozott, amelyek leginkább a 21. századi kapcsolatokban nyilvánul meg. Az online felületen például számos társkereső oldal biztosít lehetőséget az ismerkedésre. Tari Annamária 2015-ös Generációk online címú könyvében Rebecca D. Heino és munkatársai által megalkotott kifejezésre hívja fel a figyelmet, az úgynevezett „relationshopping” jelenségre, melyet az üzleti életből vettek át. Ebben az esetben az egyének a társkereső oldalakon elsődlegesen külső információk alapján hoznak ítéletet a másik személlyel kapcsolatban. A külsőségek alapján döntik el, hogy szeretnének-e kapcsolatot teremteni vagy sem. Ugyanakkor az értékorientáltság is megjelenik. A megjelenített képeken a felhasználók igyekeznek minél jobb színben feltüntetni magukat - megfigyelhető a különböző státuszszimbólumok hangsúlyozása (exkluzív helyszínek, márkás termékek által). Így a „társkereső” személy nem csupán a külső jellemvonások alapján alakítja ki véleményét, hanem a képeken reprezentált értékek értelmében is. Ugyanakkor, ha meg is történik a kapcsolatfelvétel a két fél között, az teljesen eltér a személyes kommunikációtól - például a témák, az ismerkedés tempója tekintetében. A társkereső oldalak által pedig csalódás csalódást követhet, amennyiben a felhasználók online megjelenése eltér a valóságostól. Mindez befolyásolhatja a fiatal későbbi párválasztását is.

Az internetes közösségi oldalak dominanciájának növekedése a féltékenység kialakulásának és egymás ellenőrzésének előszobájává is válhat. Tari Annamária 2015-ös adatai alapján a főiskolai hallgatók 70\%-a nyomozott már párja után, 14\%uk pedig naponta többször is megtette.

\section{A kutatás módszertana}

A kutatás, típusát tekintve, interjús technikával valósult meg, mely során a megfelelő minőségi adatok elérése, és a tanulmányban vázolt elméletek elemzése érdekében 10 darab célzott, egyéni interjús lekérdezés történt. Ezáltal lehetőségnyílt a mélyebb és pontosabb információk megszerzésére. Idődimenzióját tekintve keresztmetszeti, vagyis egyszeri beszélgetésre került sor az interjúalanyokkal, egy előre megbeszélt időpontban, 2017 márciusában. Célcsoportként mindazon, a Debreceni Egyetemen tanuló női hallgatók jelentek meg, akik 1991 és 1998 között születtek. Az alanyok ugyanakkor a nem valószínűségi mintavétel értelmében nem reprezentálják az alapsokaságot.

Az interjúk, jellegüket tekintve félig strukturáltak. Ezt az indokolta, hogy a beszélgetés során felmerülhetnek olyan lényeges elemek, melyeket fontos figyelemmel kísérni, illetve a kérdések a személyhez alkalmazkodva tehetőek fel - ezáltal egy természetesebb kapcsolatot teremtve. Mindemellett lehetőség adódik további kérdések feltevésére is, melyek kapcsolódnak az adott kutatási témához. Interjús 


\section{KEZDŐKÖR}

szituációban pedig a metakommunikáció is megjelenik, mint információforrás. Ezáltal az alanyok véleményüket nem csak szavaikkal, de mozdulataikkal is elárulják.

Az interjúvázlat dimenzióit, főbb témaköreit tekintve először a családi kapcsolatokkal és háttérrel foglalkozó kérdéseket válaszolták meg az interjúalanyok kifejtendő, nyílt kérdések formájában. Ezek között szerepelt az interjúalany családjának bemutatása („Mesélnél, kérlek a családodról?”), valamint a családi kapcsolatok kifejtésére vonatkozó kérdések is (,Milyennek itéled a kapcsolatodat a családoddal?”). A kutatás témájának szempontjából releváns kérdésként merült fel a szüleik megismerkedésének története is. Ezt követően személyes kérdésként önmaguk bemutatása következett („Mesélnél, kérlek magadról?”). E dimenzió mentén említhetőek a tanulmányaikkal összefüggő terveik, érdeklődési köreik, szabadidős tevékenységeik, párkapcsolati státuszuk és esetleges jövőbeli elképzeléseik is. A baráti társaságukat figyelembe véve meghatározták a szúk és lazább kapcsolataik számát, településbeli megközelíthetőségüket, valamint a véleményeik és egyéni nézeteik megbeszélését is körülírták.

Második kérdésblokként a párválasztással kapcsolatos általános véleményeikre koncentráltam. Viszont több esetben már magánéleti nézeteiket is bemutatták - ezáltal egyszerre több kérdést is megválaszoltak. A dimenzió alapintézményként a családra, valamint a házasságra és az élettársi kapcsolatra reflektált - melynek során nem csak véleményeik kifejtése, hanem az előnyök, hátrányok felsorakoztatására is sor került. A kapcsolati formáknál további kérdésként szerepelt, ismernek-e egyéb, alternatív együttélési formákat. Az információs korra vonatkozóan pedig felmerültek az internetes társkeresés, illetve mindezek mellett a rövid távú szexuális kapcsolatokról alkotott nézeteik.

Harmadik szegmensként a személyesebb, magánéleti kérdések következtek, a párjukkal kapcsolatos tárgykörre fókuszálva. Az interjú időpontjában párkapcsolatban élő személyek körében felmerült a megismerkedésük történetének részletezése - akárcsak a szüleik esetében. Megjelent a külső és belső jegyek alapján való jellemzés, és azon tulajdonságok elmesélése, amely először felkeltette az alanyok figyelmét párjukkal kapcsolatban. Ezt követően vagy saját elmesélésük által, vagy kisebb kérdésekkel segítve a tanulmányban felsorakoztatott befolyásoló faktorokra helyeződött a hangsúly. Velük szemben, akik az interjú időpontjában egyedülállók voltak, kérdésként szerepelt, hogy korábban éltek-e már tartós párkapcsolatban. Ennek kapcsán elmesélhették a saját, illetve a környezetükben jelenlévő, családi, baráti véleményeket. Majd a számukra ideális partner jellemzése, valamint lényegesnek vélt tulajdonságok felsorakoztatása következett. Ebből kifolyólag felmerültek a külső és belső tényezők, az iskolai végzettség, a foglalkozás - anyagi háttér, érdeklődési kör és szabadidős tevékenységek, valamint az előző partnerkapcsolatok száma. Továbbá mind az egyedülálló, mind a párkapcsolatban élő egyének esetében az ismerkedési helyszínek meghatározása is megtörtént. 


\section{KEZDŐKÖR}

Negyedik, s egyben utolsó dimenzióként a jövőképeikkel kapcsolatos kérdések következtek (milyen terveik vannak a közeljövőre, illetve melyek azok a szakmai és magánéleti elképzelések, melyeket szeretnének megvalósítani). Mindezen kérdések megfelelőnek bizonyultak a beszélgetés levezetésére, valamint a pozitív érzelmi állapot megtartására vagy esetleges visszanyerésére.

\section{A kutatás eredményei, következtetések}

Az interjúalanyok családformáit figyelembe véve egy háztartásban, származási családjukat tekintve nukleáris családként élnek. Körükben egyaránt találhatók kollégisták, albérletben élők, illetve a szülői háznál élő személyek. Baráti, társas kapcsolataik szerint az érintettek 3 és 6 fó bizalmi körbe tartozó barátról számoltak be. Ide tartoznak mindazon személyek, akiknek véleménye fontos az alanyok számára, magánéleti eseményeiket is megbeszélik velük. Lazább kapcsolatként jelölik meg azokat, akikkel nincsenek napi szintủ kapcsolatban, de telefonon, illetve az internet által nyújtott lehetőségekkel alkalmuk nyílik a heti szintű kontaktok kialakítására. Földrajzi szempontból általában a lakóhelyükhöz kapcsolódva alakítják ki baráti kapcsolataikat. A felsőoktatásba való bekapcsolódásuk által, illetve azon barátaik esetében, akik már a munka világában tevékenykednek, eltávolodásról számoltak be - viszonyaik ugyanakkor nem minden esetben alakultak át lazább kapcsolatokká.

Az alanyok közül nyolcan párkapcsolatban élnek, két személy pedig egyedülálló. Kapcsolatuk időtartamát tekintve (a lekérdezés időpontjában) másfél éves, illetve hat és fél éves kapcsolat egyaránt megmutatkozik körükben. Négyen elmondásuk szerint nagyon fiatalon ismerkedtek meg - megismerkedésük a 14-17 éves korcsoportra tehető. Ennek megfelelően többen úgy jellemezték kapcsolatukat, miszerint a jelenlegi és egyben egyetlen partnerük mellett nőttek fel, ők alakították személyiségüket, továbbá azóta is formálják egymást. A baráti kapcsolatok átalakulásával kapcsolatos feltételezés, miszerint az első párkapcsolat kialakulását követően gyengülnek a bizalmi kapcsolatok és a partner veszi át az elsőszámú barát szerepét, nem teljesült. Fontos kiemelni ugyanakkor, hogy a partnerüket több kategóriába is besorolták. Volt, aki a szűk baráti körének tagjaként is megjelölte, illetve volt, aki önmagukra már a közös albérletben élő kiscsaládként tekint.

A továbbiakban, a tanulmány szempontjából lényeges dimenziókban kerülnek kifejtésre az interjúalanyok válaszai. Ilyen a házasság vagy élettársi kapcsolat közötti választás feltérképezése a házasság intézménye- és átalakulásként, valamint az ismerkedési színterek és kapcsolatok időtartamának változásainak vetülete. Továbbá a szakirodalmak által bemutatott partnerszelekciót befolyásoló tényezőkre koncentrálok, mint az életkor, a lakóhely, a vallási hovatartozás, az iskolai végzettség és az anyagi igények. 


\section{KEZDŐKÖR}

\section{A házasság intézménye - és átalakulása}

Összességében elmondható, hogy a származási családot az alanyok többsége a biztonsággal azonosítja:

„Nekem alapvetôen egy biztonság, egy olyan támasz, amit úgy nem kap meg az ember család nélkül. Alapvetően ugye az a szocializációs színtér, aminek köszönhetem, hogy én az lettem, aki... ez ugye a családom. Egy olyan hely, ahova így vissza tudsz menni." (23 éves, kapcsolatban élő nő)

„A család számomra mindenképpen olyan embereknek az összessége, akik megértenek, elfogadnak és szeretnek - úgy, ahogy vagy. És nálam ez a legfóbb szempont. (...) akikkel tényleg számíthatok bármire, és akik tényleg mindig ott vannak, amikor szükség van rájuk és én is ott vagyok nekik..." (22 éves, kapcsolatban élő nő)

Eltérések figyelhetőek meg a házassággal illetve élettársi kapcsolattal összefüggő meglátásaik, véleményeik és saját döntéseik esetében. Az interjúalanyok között is voltak, akik a szakirodalom által leírt tendenciáknak megfelelően, a házasság intézményét nem feltétlenül tartják szükségesnek, a megnevezésben a "csak egy papír” kifejezést alkalmazták.

„A házasság úgymond csak egy papír. Viszont a társadalom számára még mindig elég nagy erővel bír, úgy gondolom... Tehát úgymond inkább ilyen társadalmi formaságnak ítélem a házasságot... Viszont szerintem mindenképp egy kellemes érzés lehet, hogy ha tényleg úgy a férj-feleség viszonyban állnak egymással a felek. (...) Egyébként úgymond a magam részéről preferálom a házasságot. Tehát, ha egyszer odakerül a sor, nyilván én is szeretnék egyszer majd férjhez menni." (22 éves, kapcsolatban élő nő)

A részlethez hasonlóan minden olyan interjúalanynál felmerült ez a fajta kettősség, akik az élettársi kapcsolatot is egyaránt elfogadott életformának tekintik. Viszont az általam megkérdezett személyek egytől-egyig házasságot kötnének, amenynyiben párkapcsolatuk eléri a megfelelő időpontot.

„Családról akkor tudok gondolkozni, ha a szülők házasok. És úgy gondolom, hogy ez több egy papírnál, abszolút... Ez egyszerüen egy hatalmas elkötelezödés a másik iránt. Akkor válik teljessé a kapcsolat." (24 éves, egyedülálló nő) 
www. metszetek.unideb.hu

\section{KEZDŐKÖR}

Továbbá magát a házasságot és élettársi kapcsolatot szorosan összekapcsolják a gyermekvállalással illetve a gyermekek nevelésével is:

„Ha például gyereket akarnak, akkor szerintem az egyértelmü, hogy házasságon belül kell, hogy megvalósuljon. Ha csak élettársi viszonyban vannak, én azt mondanám, hogy például a gyerekvállalás az nem megoldható. Szerintem ez a házasság szent kötelékén belül kell, hogy megtörténjen." (21 éves, kapcsolatban élő nő)

Az interjúalanyok közül voltak, akik kifejezetten házasságpártinak nevezték magukat, de a házasság előtti együttéléstől nem zárkóztak el. A szülők anyagi helyzete ugyanakkor a partnerrel való összeköltözés vagy házasságkötés szempontjából nem merült fel releváns befolyásoló tényezőként.

Az ideális korokat illetően (a házasság, összeköltözés, és gyermekvállalás értelmében) jellemzően a saját nemükkel kapcsolatban tudtak árnyaltabb képet adni, s általában a gyermekvállalással összekötve - az egészségügyi kockázatokra utalva. A házasodási életkor tervezett időpontja az alanyok esetében a statisztikai adatoknak megfelelően alakulnak, 25-29 éves koruk közt szeretnének házasságot kötni. Tehát a kitolódási tendencia általuk is igazolást nyert.

Az élettársi kapcsolatokat, $s$ azok terjedését, mint életforma, elismerik az alanyok. Ugyancsak alátámasztották azt az állítást, miszerint ez a fajta együttélési típus sokkal nagyobb teret enged az egyének szabadságának. Továbbá véleményük szerint a kötöttségek hiánya is megfigyelhető - könnyebben hagyhatnak fel egy élettársi együttélés során a felek az adott kapcsolattal, ha az megromlik. Egyesek viszont úgy gondolják, hiába nem köttetik meg írásos formában maga a kapcsolat, a közös élet a szerelmen, az érzelmi megalapozottságon nyugszik. Egységes, összhangba hozható meglátások ugyanakkor nem születtek. Vannak, akik alátámasztják az érzelmi megalapozottságot, míg mások úgy gondolják, azért nem házasodnak össze az élettársi kapcsolatban élő felek, mivel valamilyen tényező az egyik vagy mindkét fél számára akadályt jelenthet. Ez lehet a túlzott elköteleződéstől való félelem, a szabadság feltételezett hiánya, vagy anyagi okokból bekövetkezett megfontolás, esetleg az érzelmi instabilitásra utaló jel.

Az alternatív együttélési formák esetében megjelent a látogató partnerkapcsolat, valamint a próbaházasság intézménye - mint a házasság előszobája is. Ebben az esetben érvényes Bukodi Erzsébet (2002b) leírása, miszerint ez egyfajta előzetes próbálkozásra ad lehetőséget.

„Szerintem az egy jó dolog. Szerintem az is egy tesztje annak, hogy múködnek-e együtt, és hogy addig ne kötelezzék el magukat egymás mellett, amíg ez nem biztos." (23 éves, kapcsolatban élő nő) 


\section{KEZDŐKÖR}

Mindezek mellett előfordult a különböző patchwork és mozaik családok említése, valamint a nyitott házasság is felmerült több alannyal folytatott beszélgetésem során is. A próbaházasságot azok, kik megemlítették, megfelelő együttélési formának tekintik. Viszont volt, aki azzal a kikötéssel érvelt mellette, hogy kizárólag abban az esetben tudja elfogadni, ha a cél a házasság. Tehát összességében, a házasság intézményének tagadása nem tapasztalható az interjúalanyok gondolkodásmódjában. Engler Ágnes $(2014,2018)$ leírása ezáltal alátámasztottá vált, hiszen az egyetemisták körében továbbra is tapasztalható a házasodási kedv.

\section{Ismerkedési színterek és a kapcsolatok időtartama}

Az információs korra jellemző internetes társkeresésre az alanyok döntő többsége, mint veszélyforrásra tekint. Negatív és pozitív érveket figyelembe véve igyekeztek meghatározni az online felületen történő párkeresés jellemzőit. Az online párkeresőkre inkább jellemző szerintük az önbecsülés hiánya és a megerősítés, a külső visszacsatolások keresése. Továbbá az a rizikó faktor, miszerint olyan személyek is felregisztrálhatnak az adott, online felületre, akik álinformációkkal színesített profillal csapják be a velük kapcsolatba kerülő felhasználókat.

„Szerintem ez elég veszélyes, mert, hogy ugye ott bármit-bárki írhat magáról és hát nem feltétlen az igazat. Szerintem veszélyes, de lehet... valakinek bejön." (21 éves, kapcsolatban élő nő)

Pozitívumként jelent meg az, hogy vannak, akiknek ez a fajta társkeresés válik sikeressé. Szinte minden alany tudott említeni egy példát a közeli rokonságában, vagy távolabbi ismerősi körében, esetleg az oktatási intézményéhez kapcsolódva olyan személyt, aki így találta meg a társát.

„Én úgy gondolom, hogy ha kellő intelligenciával használja az ember, sosem tudhatjuk, hogy nem-e válik be." (24 éves, egyedülálló nő)

Az idézetben olvasható érvelés ellenére megjelentek azok is, akik egyáltalán nem tudják elképzelni önmagukkal kapcsolatban az e féle párkeresést. Az online felületek által biztosított kommunikációs csatornát pedig egyik interjúalany sem említette, mint féltékenységre okot adó tényezőt.

A rövidtávú szexuális kapcsolatok összefüggésében a megkérdezett személyek közül többen is azt vallották, hogy nem ítélik el ezt a fajta viszonyt, hiszen vannak olyan személyek, akiknek „erre van szükségük”. Vegyes kép mutatkozik a történeteket megvizsgálva is. Egyesek úgy fogalmaznak, hogy akik körülveszik őket, nem hívei 


\section{KEZDŐKÖR}

ennek az „életmódnak” vagy ideiglenes állapotnak. Mások ismernek történeteket, távolabbi személyekkel kapcsolatban van róla tudomásuk. Viszont megjelenik az önbecsülés, mint fontos kritérium - melyet a nőknél kiemelt tényezőnek tekintenek. Továbbá, annak a kikötése, hogy mindkét fél helyén tudja kezelni a kapcsolatot. Mindemellett felvetődik az érzelmi stabilitás, az érzelmi kötődés és a bizalom igénye a szexuális kapcsolatok kialakítása során, melyet az alanyok döntő többsége rövidtávon nem tudna biztosítani.

Az ismerkedési helyszínek megváltozása a megkérdezettek által szintén beigazolódott. Korábban, szüleik megismerkedése a bálokhoz, oktatási intézményekhez, munkahelyi környezethez vagy a szabadidő eltöltéséhez kapcsolódott. A jelenlegi helyszínek esetében elsőszámú helyen jelölték meg a szórakozóhelyeket illetve egyéb alkoholfogyasztásra alkalmas pubokat. Emellett kiemelésre kerültek a felsőoktatási intézmények, a vallási közösségek, a koncertek, a munkahely és a különböző konferenciák, előadások is. A szórakozóhelyeken való ismerkedés alátámasztásául szolgál, miszerint az alanyok közül négyen is vagy egy koncerthez, vagy egy bulihoz kötik a megismerkedésüket. Az ilyen típusú programokkal kapcsolatban viszont már megjelent a féltékenység, melyet többen is említettek. Ez nézeteltérésekhez vezetett, melyet az együtt töltött idő és egymás mélyebb megismerése csillapított.

„Nekünk nagyon sok nézeteltérésünk volt, mert... az elején nagyon féltékeny típus volt. (...) Senki nem nézhetett rám, senki nem szólhatott hozzám. Úgyhogy időben meg is mondtam neki, hogy soha többet nem megyek el vele bulizni, mert minden egyes buliba veszekedésbe fulladt." (23 éves, kapcsolatban élő nő)

\section{Partnerszelekciót befolyásoló tényezők megjelenése az érintettek körében}

Pszichológiai megközelítés szempontjából a párkapcsolatban élő alanyok jelentős részénél a lélektani hasonlóság elmélete valamint komplementaritás tétele figyelhető meg. Az idealizált partnerképek esetében pedig fennáll a szülőimágó keresésének elmélete, valamint a rokonsági kapcsolataikban látott mintákhoz való kötődés. Tehát a családi, rokoni szálak, mint elsődlegesen befolyásoló faktorok jelenléte figyelhető meg. Továbbá egyes interjúalanyoknál vagy az édesapjuk és partnerük külső jellemzése volt megegyező, vagy belső tulajdonságaik voltak azonosak, leírásaik alapján.

A tartós párkapcsolat megalapozásához számos jellemvonás hozzájárulhat. Ilyen erényeket a párjukkal kapcsolatban is kiemeltek az alanyok, vagy az ideálisnak tartott partner esetében fogalmazták meg: 


\section{KEZDŐKÖR}

„Nagyon szeretem, ha egy férfi gyakorlatias, amellett, hogy müvelt. (...) És a humor... az nekem nagyon fontos. (...) Meg tényleg ez a kicsit játékos, gyermek-én, hogy tudja azt is szabadon engedni." (24 éves, egyedülálló nő)

„Nekem a gyerekekhez, a fiatalokhoz, meg úgy egyáltalán az emberekhez való viszonya az, amit mai napig is nagyon nagyra értékelek benne és fel is nézek rá emiatt. (...) Meg a jó kedélyüsége, tehát mai napig én minden viccén nevetek, még akkor is, hogy ha húszan mondják mellettem, hogy ez egyáltalán nem vicces, nekem vicces. Úgyhogy ez, igen, meg a humor." (23 éves, kapcsolatban élő nő)

Az érintettek és partnereik közötti életkorbeli különbségek területén az esetek döntő többségében 1 és 4 év közötti eltérés figyelhető meg, a férfiak javára. Az idősebb férfipartner választásának indokoltságát pedig több interjúalany is megfogalmazta, és okát a férfiak későbbi érésében jelölik meg.

„Azt gondolom, hogy a férfiak tényleg sokkal később érnek, mint a nők, tehát a férfiaknak kell egy... legalább 21 éves kor, amikor azt mondom, hogy... tényleg ki tudjanak alakítani egy értelmes párkapcsolatot." (23 éves, kapcsolatban élő nő)

Az egyedülálló alanyok körében az ideálisnak tartott partnerrel kapcsolatban is felmerül az életkor, mint befolyásoló tényező.

„Alapvetően nem számítana annyira nekem, de... minimum annyi idős legyen, mint én. De inkább idôsebb. Ennek rém egyszerú oka van, azt tapasztalom, meg azt látom, hogy agyban... agyilag nem érnek annyira gyorsan. Mondjuk ez elvileg tény is, tehát, hogy bizonyított tény." (24 éves, egyedülálló nő)

A lakóhelyi különbségek az interjúalanyok esetében nem okoztak problémát. A párkapcsolatban élő személyek közül csupán 2 személy van, akik kevesebb időt tudnak a partnerükkel tölteni, külföldi munkavállalás vagy eltérő lakóhely miatt. A település lélekszáma szerint viszont alátámasztottá válik, hogy a kisebb lakosságszámú településről származók korábban ismerték meg egymást - vagy ismerősök által, vagy azonos oktatási intézményben eltöltött tanulmányaik kapcsán. A nagyobb lélekszámú településeken pedig sokan tudatában sem voltak adott esetben annak, hogy akár egy oktatási intézményben is tanultak.

A vallási hovatartozás az esetek döntő többségében nem releváns befolyásoló tényező a párkapcsolatok szempontjából. Eltérő nézetek ugyanakkor megfigyelhetőek, mint például a hit jelenléte, vagy szöges ellentéte - az ateizmus. Viszont a lényeg 


\section{KEZDŐKÖR}

minden esetben egymás elfogadása, a megváltoztatásra való törekvés nélküli szeretet, a harmonikus kapcsolat kialakítása.

A szülők véleménye minden esetben fontos volt, hiába felnőtt korban járó személyekről van szó. Mindez nem csupán az egyedülálló alanyoknál merült fel, hanem a párkapcsolatban élő személyeknél a szülők és az alanyok partneri közti viszonyt megvizsgálva is. Azonban egyetlen érintett sem emelte ki korlátozó, befolyásoló tényezőként a szülőt - minden interjú során kizárólag pozitívumokat említettek.

„Apának már az is első perctől kezdve az volt, hogy úgy köszönt neki, hogy „Tiszteletem!”, szóval ez neki már nagyon... és szóval így tényleg nagyon szeretik. Meg nagyon sokat van ugye ott nálunk, amikor itthon van, meg én is náluk... szóval így neki is, meg nekem is nagyon jó a kapcsolatom a szüleivel. Úgy már szinte családtag. Anya is mindig azt mondja, hogy olyan, mint ha a fia lenne."(19 éves, kapcsolatban élő nő)

Az iskolai végzettség kapcsán az egyedülállók körében szintén megtalálható a homogámiára, valamint az azonos intellektuális és műveltségi szintre való törekvés:

„Nekem fontos, hogy tudjak beszélgetni. (...) Tehát inkább akkor úgy fogalmazok, hogy nekem fontos, hogy végzettségtöl függetlenül nyitott legyen az új ismeretekre. Tehát olvasás, előadások, kulturális rendezvények. Tehát, hogy ha erre nyitott, akkor nem zavarna, ha alacsonyabb a végzettsége lenne. De alapjában nem ez a tapasztalat. Tehát emiatt mondom azt, hogy jobb, ha magasabb, mert akkor úgy alapból a képzés révén is, de közben is... van egy olyan intellektuális nyitottsága és tudása, ami másra annyira nem jellemző.” (24 éves, egyedülálló nő)

A párkapcsolatban élő alanyok partnerei közt található doktorandusz, oktató és egyetemi hallgató is. Ezáltal az érintett személyek körében megfigyelhető a Bukodi Erzsébet (2005) által vázolt jelenség, miszerint előtérbe kerülnek az iskolai végzettségnek megfelelő párkapcsolatok.

A munkaerőpiaci pozícióval kapcsolatosan nem a konkrét foglalkozás meghatározása történt, hanem az anyagi stabilitás igénye, amely mind a párkapcsolatban élők körében, mind az egyedülálló személyek esetében megfigyelhető. Mindezt a konfliktusok elkerülése végett is fontos kitételnek tekintették.

„Annyi a lényeg anyagi szempontból, hogy stabilitás legyen. Tehát, hogy ne legyen az, hogy alkalmi munkákból tengödünk, meg ilyenek. És ez most nem lenézésből, mert egyszerüen ez szerintem minden nőnek... minden kapcsolat- 


\section{KEZDŐKÖR}

ban ott van, hogy legyen egy olyan háttér, ami nyújt egy bizonyos stabilitást." (24 éves, egyedülálló nő)

Ezáltal Szilágyi Vilmos 1978-as megfogalmazása, miszerint a gazdasági szempontok felett az érzelmi és intellektuális igények vették át a szerepet, kettős értelmezést nyert. Fontosnak tartják ugyan az érzelmi, valamint szexuális vonzódást, de nem feltétlenül mondható el az, hogy a gazdasági-anyagi szempontok háttérbe kerültek volna. Ez főleg a nőkre igaz a szakirodalom szerint, nekik fontos az anyagi biztonság.

A párkapcsolatot megelőző nemi kapcsolatok nem csupán az időtartamukban vagy intenzitásukban voltak meghatározóak, hanem a számukban is. Az egyedülálló alanyok esetében is felmerült, mint jövőbeni partnerükkel szembeni befolyásoló faktor. A partnerkapcsolatban élő felek körében pedig ugyancsak megjelent korábban, a jelenlegi társukkal való viszony kialakítása során, mint hangsúlyos komponens.

„A páromnak egy kapcsolata volt és azt is nehéz volt elengedni, hogy egyáltalán neki volt egy kapcsolata, hogy volt egy nőhöz kötődése. Valakit ez abszolút nem zavar, mert maga mögött tudja hagyni a múltat. De én nem teljesen..." (23 éves, kapcsolatban élő nő)

Az utolsó blokkban felmerülő, jövőre vonatkozó kérdések esetében a párkapcsolatban élő felek mindegyike közös jövőt tervez jelenlegi partnerével. Több tartós párkapcsolatban felmerült az eljegyzés, mint közeljövőre vonatkozó esemény. A házasság időpontjának tervezése elsősorban a négy évnél tartósabb kapcsolatoknál került előtérbe. Ennek megfelelően pedig az a következtetés vonható le, hogy lényeges elem a partnerrel együtt töltött idő mennyisége a megfelelő bizalom kialakulásához, és jövőbeli tervek szövögetésének megalapozása céljából.

\section{Összegzés}

Összegzésként megállapítható, hogy „a párválasztás és a partnerkapcsolat problematikája interdiszciplináris megközelítést igényel" (Buda - Szilágyi 1988: 17). A konklúziók levonásával kapcsolatban, a kutatási kérdések esetében alátámasztottá vált az interjúknak megfelelően az, hogy a házasság intézménye továbbra is kiemelkedő helyen szerepel a felsőoktatásban tanuló női hallgatók körében, mint tervezett kapcsolati forma. Továbbá az is, miszerint a magasabb iskolai végzettséggel rendelkező egyén magasabb iskolai végzettségű személlyel alakít ki párkapcsolatot, ezzel kapcsolati homogámiára törekedve. Hiszen 8 párkapcsolatban élő személy közül 6 alany 


\section{KEZDŐKÖR}

él felsőoktatási végzettséggel rendelkező partnerrel, tartós kapcsolatban, illetve a két egyedülálló személy szintén diplomás partnert tervez.

Az életkorok kitolódása, valamint a halasztási mechanizmus a megkérdezett személyek alapján szintén megfigyelhető. A statisztikák által vázolt kép, miszerint a nők házasságkötése 25 éves kor felett fog megtörténni, az alanyok jövőbeli terveik, és az azokhoz rendelt időintervallumoknak megfelelő. A gyermekvállalás a jövőbeli tervek körében szintén megfigyelhető. E lépést viszont fontos, hogy megelőzze az összeköltözés, az eljegyzés és házasság - mindezen elemek sorrendje alanyonként eltérő helyen szerepelt. Továbbá a biztos anyagi háttér és a szakmai karrier megalapozottsága is lényeges pont. Ugyancsak fontos faktorként jelenik meg az iskolai végzettség, amely a későbbi munkaerőpiaci és anyagi helyzet előrejelzője is lehet. Ezzel szemben viszont a származási, valamint vallási alapon megnyilvánuló homogámia az alanyok esetében háttérbe szorult.

Kulcsfontosságú tényező ugyanakkor az interjúkból levont következtetéseknek megfelelően a közös érdeklődési kör is, mely a kutatás során felsorakoztatott tényezők szempontjából nem került külön kiemelésre. Mégis, az interjúalanyok válaszai által lényeges megfogalmazni, hogy az azonos érdeklődési terület, illetve szabadidős tevékenységek nagymértékben befolyásolják az egyének partnerszelekcióját. Ez az érdeklődési kör lehet a zene - mely több alanynál is felmerült, vagy akár a tudásszomj is, mely szintén kiemelésre került, felsőoktatási hallgatók lévén.

Lényeges szempontként jelent meg a hallgatók körében az egyenrangúság, az, hogy a felek tekintsék egymást azonos feleknek. Ez a nézet párkapcsolatban élő és egyedülálló személyek körében egyaránt megfogalmazódott.

\section{Irodalom}

Albert J. - Farkas I. - Leveleki M. (2002): Szociológia. Möbius Print, Nyíregyháza.

Bereczkei T. - Rozsnyai, M. - Vekerdy, T. (szerk.) (2012): Választások. Párválasztás, Pályaválasztás, Óvoda- és iskolaválasztás. SAXUM Kiadó, Budapest.

Bereczkei T. (2012): Rejtett indítékok a párkapcsolatban. Vonzalom, párválasztás, szexualitás. Kulcslyuk Kiadó, Budapest.

Buda B. - Szilágyi V. (1988): Párválasztás. A partnerkapcsolatok pszichológiája. Gondolat, Budapest.

Buda B. (2002): Szexuális viselkedés. Animula Kiadó, Budapest.

Bukodi E. (2001): A párkapcsolat-formálódás és -felbomlás néhány társadalmi meghatározója. In.: Nagy I. - Pongrácz T. - Tóth I. Gy. (szerk.): Szerepváltozások: Jelentés a nők és férfiak helyzetérôl 2001. TÁRKI - Szociális és Családügyi Minisztérium, Budapest, 88-112. 


\section{KEZDŐKÖR}

Bukodi E. (2002b): Házasság vagy élettársi kapcsolat: ki mikor mit (nem) választ. In.: Statisztikai Szemle 2002, 80. évfolyam 3. szám. 227-251. oldal. Központi Statisztikai Hivatal http://www.ksh.hu/statszemle_archive/2002/2002_03/2002_03_001.pdf Utolsó letöltés: 2017.10.25.

Bukodi E. (2002a): Házasság - élettársi kapcsolat - válás: társadalmi meghatározottságok. Életmód - időmérleg. Központi Statisztikai Hivatal, Budapest.

Bukodi E. (2004): Ki, mikor, kivel (nem) házasodik? Párválasztás Magyarországon. Századvég Kiadó Andorka Rudolf Társadalomtudományi Társaság, Budapest.

Bukodi E. (2005): Partnerszelekció a házasságokban és az élettársi kapcsolatokban. In.: Demográfia, 2005. 48. évf. 2-3. 218-253. http://demografia.hu/kiadvanyokonline/index.php/demografia/article/viewFile/ 590/442. Utolsó letöltés: 2017.10.25.

Dienes A. (2014): Csábításra születtünk. A párválasztás pszichológiája. Libri Kiadó, Budapest.

Lőrincz L. (2006): A vonzás szabályai - Hogyan választanak társat az emberek? BCE Szociológiai és Társadalompolitikai Intézet. In.: Szociológiai Szemle 2006/2, 96110.

http://www.szociologia.hu/dynamic/0602lorincz.pdf Utolsó letöltés: 2017.10. 25.

Monostori J. - Murinkó L. (2015): Család és háztartásszerkezet. In.: Monostori J. Őri P. - Spéder Zs. (szerk.): Demográfiai Portré 2015: Jelentés a magyar népesség helyzetéről. Központi Statisztikai Hivatal Népességtudományi Kutató Intézet, Budapest 153-171.

http://demografia.hu/kiadvanyokonline/index.php/demografiaiportre/article/ view/2485/2483 Utolsó letöltés: 2017.10.25.

Murinkó L. (2013): Első elköltözés a szülői házból Magyarországon. A szülői ház elhagyásának időzítése, párkapcsolati környezete és családi háttér szerinti különbségei. Központi Statisztikai Hivatal Népességtudományi Kutatóintézete, Budapest.

Murinkó L. - Rohr A. (2018): Párkapcsolat, házasságkötés. In.: Monostori J. - Őri P. Spéder Zs. (szerk.): Demográfiai Portré 2018: Jelentés a magyar népesség helyzetérôl. KSH Népességtudományi Kutató Intézet, Budapest. 9-28.

http://demografia.hu/kiadvanyokonline/index.php/demografiaiportre/article/ view/2741/2629 Utolsó letöltés: 2019.02.23.

Pistyur V. (2003): A szingli lét dilemmái. Miskolci Egyetem Kulturális és Vizuális Antropológiai Tanszék. In.: Bakó B. - Tóth E. Zs. (szerk.) (2008): Határtalan nők. 


\section{KEZDŐKÖR}

Kizártak és befogadottak a női társadalomban. Nyitott Könyvműhely, Budapest, 201-225.

Pongrácz T. (2011): A családi értékek és a demográfiai magatartás változásai. Központi Statisztikai Hivatal Népességtudományi Kutatóintézet, Budapest.

Pongrácz T. (2012): Párkapcsolatok. In.: Őri Péter - Spéder Zsolt (szerk.): Demográfiai Portré 2012: Jelentés a magyar népesség helyzetérôl. Központi Statisztikai Hivatal Népességtudományi Kutató Intézet, Budapest, 11-20. oldal http://demografia.hu/kiadvanyokonline/index.php/demografiaiportre/issue/view/35 Utolsó letöltés: 2017.10.25.

S. Molnár E. (2001): Élettársi együttélések - tények és vélemények. In.: Nagy I. Pongrácz T. - Tóth I. Gy. (szerk.): Szerepváltozások: Jelentés a nők és férfiak helyzetéről 2001. TÁRKI - Szociális és Családügyi Minisztérium, Budapest, 65-87.

Spéder Zs. - Kapitány B. (2007): Gyermekek: vágyak és tények. Dinamikus termékenységi elemzések. Központi Statisztikai Hivatal Népességtudományi Kutatóintézet, Budapest.

Statisztikai tükör (2014): Családtípusok és párkapcsolati formák változása a népszámlálási adatok tükrében. Központi Statisztikai Hivatal 2013/115. Budapest, $1-7$.

https://www.ksh.hu/docs/hun/xftp/stattukor/csaladtipusok.pdf Utolsó letöltés: 2017.10.25.

Statisztikai tükör (2015): Oktatási adatok, 2015/2016 (előzetes adatok). Központi Statisztikai Hivatal 2015/97. https://www.ksh.hu/docs/hun/xftp/idoszaki/oktat/okt1516.pdf Utolsó letöltés: 2017.10 .25 .

Székely L. - Szabó A. (szerk.) (2016): Magyar ifjúságkutatás 2016. Az ifjúságkutatás első eredményei. Ezek a mai magyar fiatalok! Új Nemzedék Központ Nonprofit Kft. http://www.ujnemzedek.hu/sites/default/files/magyar_ifjusag_2016_a4_web. pdf Utolsó letöltés: 2019.02.23.

Szilágyi V. (1978): Pszichoszexuális fejlődés - párválasztási szocializáció. Tankönyvkiadó, Budapest.

Tari A. (2015): \#yz Generációk online. Klinikai pszichológiai és társadalom-lélektani szempontok az Információs Korban. Tericum könyvkiadó, Budapest.

Tóth 0. (2012): Társadalmi integráció és család. In.: Kovách I. - Dupcsik Cs. - P. Tóth T.- Takács J. (szerk.): Társadalmi integráció a jelenkori Magyarországon. Tanulmányok. Argumentum Kiadó, MTA Társadalomtudományi Kutatóközpont (Szociológiai Intézet), 369-383. 
www. metszetek.unideb.hu

\section{KEZDŐKÖR}

Utasi Á. (2001): A fiatal egyedülálló nők párkapcsolati esélye. In.: Nagy I. - Pongrácz T. - Tóth I. Gy. (szerk.): Szerepváltozások: Jelentés a nők és férfiak helyzetéről 2001. TÁRKI - Szociális és Családügyi Minisztérium, Budapest, 113-134.

Végh J. (2010): Társas játékok - A sikeres párválasztástól a boldog párkapcsolatig. Vita Plaza Kft., Budaörs. 